\title{
17 Determinants of Chinese Exports in Information and Communication Technology (ICT) Products:
}

\author{
A Firm-Level Analysis
}

\section{Kunwang Li and Bingzhan Shi}

\section{Introduction}

As information and communication technology (ICT) products are becoming more common in society, the development and diffusion of ICT, because of its high-tech content, has been widely seen as a major contributor to the growth of productivity, and economic growth more generally. First, ICT is known as a key tool for enhancing innovation, and promoting technological progress, resulting in the growth of total factor productivity (TFP) in the ICT sector itself. Second, firms tend to be engaged in large-scale investment in ICT in capital formation to improve productivity. The two factors together constitute the direct contributions made by ICT to productivity growth (Jorgenson et al. 2008). Trade can play an important role in fostering development of the ICT sector. Studies suggest that strong export performance in ICT products yields higher economic growth rates and improvement in productivity (Greenaway et al. 1999, Rodrik 2006, Hausmann et al. 2007). For this reason, an increasing number of countries have introduced polices and allocated more resources to encourage exports from the ICT sector.

China is now the largest producer of ICT goods in the world. In 2007, of the world total, China produced 48 per cent of phone handset, 46 per cent of personal computers, 42 per cent of colour TVs, 65 per cent of monitors, 58 per cent of program-controlled switchboards, and 57 per cent of digital cameras. Based on China's Annual Survey of Industrial Firms (1998-2007), we calculate that the share of the ICT sector in manufacturing value-added products increased from 6.3 per cent to 9.1 per cent over the period 1998-2007, but the ICT sector contributes 15.6 per cent on average to manufacturing productivity growth in the same period. The trade data shows that the development of Chinese ICT goods relies heavily on export markets. During the period 1998-2007, export of ICT goods accounts for about 40 per cent of the sector's total sales. 
The purpose of this chapter is to examine the determinants of China's exports of ICT goods in two dimensions: export quantity and quality. Our main finding is that China's ICT export growth is mainly achieved by producing a high quantity of low quality. Furthermore, the volume and pattern of China's ICT exports are largely determined by foreign direct investment (FDI), processing trade and government supporting policies. While processing trade mainly accounts for the high quantity and low quality of China's ICT exports, FDI and government policy may help to upgrade the export quality, but decrease export quantity. The challenge for China is, therefore, to upgrade its ICT export quality while maintaining its ICT export volume through a combination of different policies.

The chapter is organised as follows: In Section 2, we describe the pattern of growth of Chinese ICT exports; Section 3 present the econometric model and introduces data used in the analysis; and, Section 4, presents and discusses the estimation results.

\section{Stylised Facts about China's ICT Exports}

China's export has expanded at the pace of almost 14.5 per cent per annum from 1995 to 2010, while the world's growth rate is only 7.2 per cent over the same period. As a result, China's share in total world exports rose from four per cent to 11.8 per cent over the same period. China has, in the past, held a large share of the world market for traditional, labour-intensive industries, such as textiles, shoes and clothes, and is now rapidly enlarging its share in high technology industries, such as ICT products. Figure 17.1 shows the shares of ICT exports in the world total exports of these products by those main producers: 
Figure 17.1 Share of world's ICT exports of the main producers

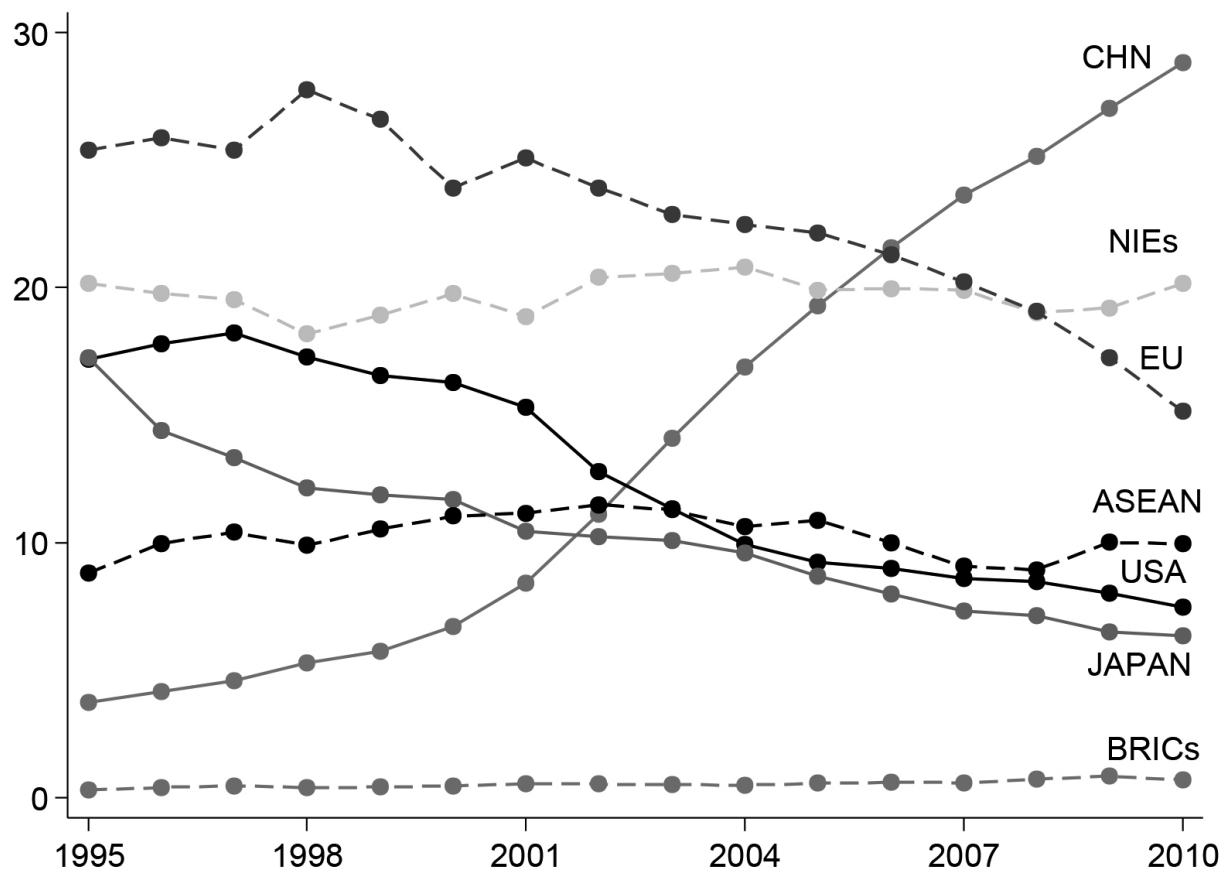

Note: NIEs: Hong Kong, Singapore, South Korea, Taiwan; ASEAN: Thailand, Indonesia, the Philippines, Malaysia; EU: the EU15; BRICS: Brazil, Russia, India, China, South Africa.

Source: CEPII BACI Database, authors' calculation.

China's share of the world's ICT exports has risen fast, from only three per cent in 1995 to 30.1 per cent in 2010. In contrast, the share of all other major producers decreased over this period. The relative changes demonstrate that China has been gaining increasing competitiveness in producing and exporting ICT products in the world markets. China's ICT export is already exceptionally high (Rodrik 2006). In illustrating a cross-country relationship between sophistication of exports and the per capita income, Dani Rodrik finds that 'China is an outlier in terms of the overall sophistication of its exports: its export bundle is that of a country with an income-per-capita level three times larger than China's'. Peter Schott (2008) arrived at a similar conclusion. We examine this conclusion from the perspective of the changing market share of China's ICT products. Figure 17.2 illustrates a cross-country relationship between export structure and per capita income, where export structure is measured by the ratio of ICT products in the country's total export: 
China: A New Model for Growth and Development

Figure 17.2 Per capita income and export structure

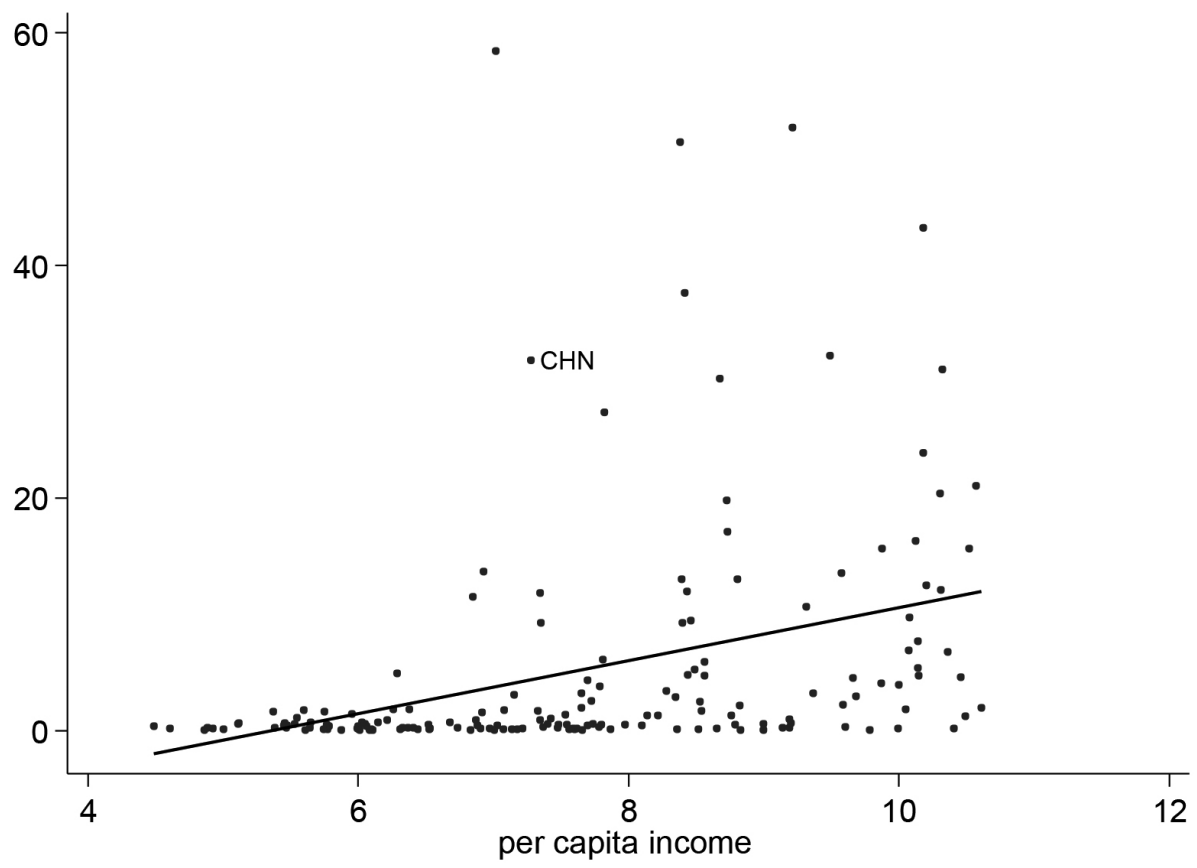

Source: CEPII BACI Database and WDI, authors' calculation.

China's ICT export ratio of its total exports is also an outlier as compared with its per capita income level, which verifies Rodrik's (2006) and Schott's (2008) conclusion.

China's ICT exports are, however, dominated by foreign firms, including wholly foreign owed firms (WFOF) and joint ventures (JV). These firms are largely responsible for the ever-growing share of China's ICT exports and they played a dominant role in increasing China's ICT exports during 2000-2006. Figure 17.3 illustrates this role: 
Figure 17.3 Breakdown of China's ICT exports by category of firms

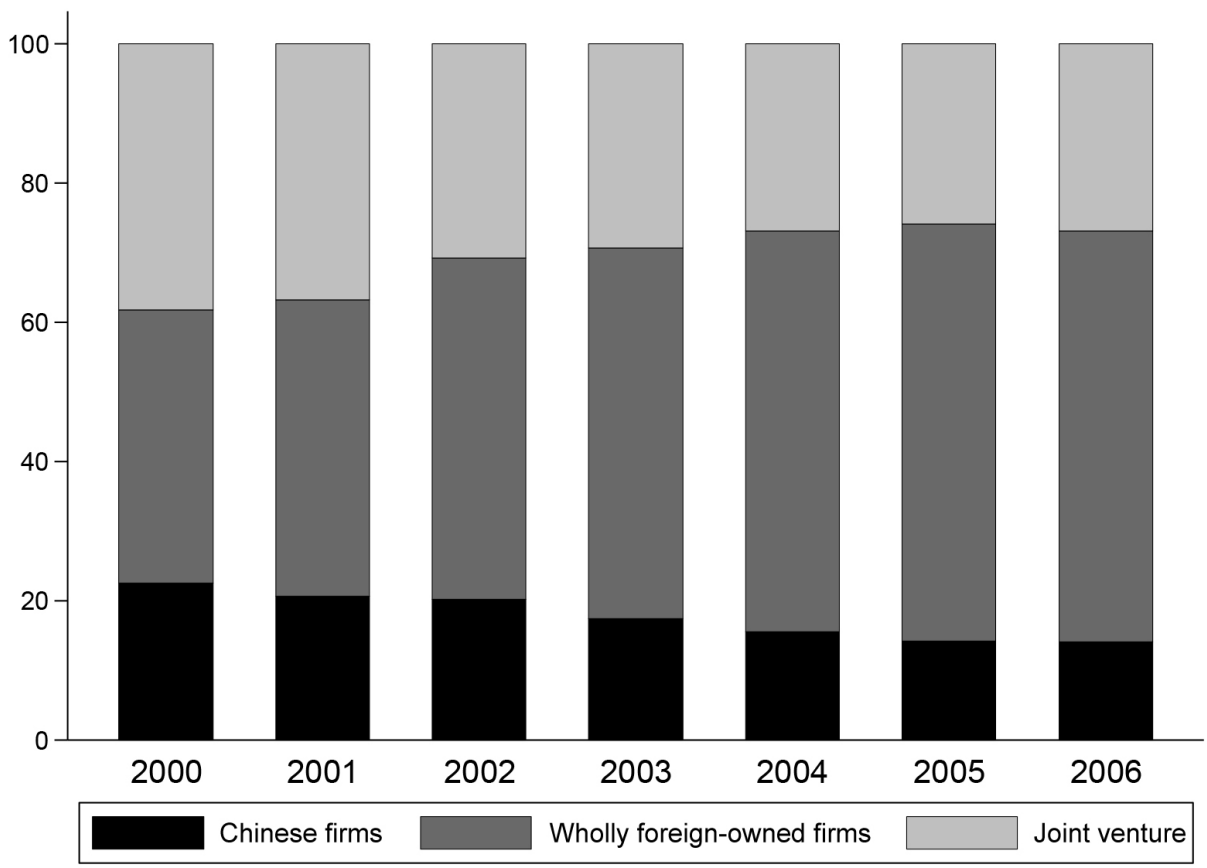

Source: Chinese Customs Trade Statistics (CCTS), 2000-2007, authors' calculations.

It is clear that foreign affiliates are at the core of China's ICT exports. They accounted for 77.4 per cent of China's ICT exports in 2000, and increased to 85.9 per cent in 2006. The increasing role of foreign affiliates in China's ICT exports was entirely due to WFOF, which accounted for more than half of China's ICT export since 2003. Chinese domestic firms are clearly losing ground in ICT exports, and are responsible for less than 20 per cent of China's ICT exports.

Also, China's ICT exports have been driven by the reorganisation of production in Asia. China is used as an export base by firms located in advanced Asian economies, which, instead of exporting finished goods to the US and European markets, now export intermediate goods to their affiliates in China. China's exports have skyrocketed and have displaced Japan's and NIEs' exports at an accelerated pace. This triangular trade pattern can be seen from the extensive role played by China's processing trade. Table 17.1 shows the processing, ordinary and other custom regime shares in China's ICT exports. 
China: A New Model for Growth and Development

Table 17.1 Breakdown of China's ICT exports by custom regime (\%)

\begin{tabular}{l|r|r|r|r|r|r|r}
\hline & $\mathbf{2 0 0 0}$ & $\mathbf{2 0 0 1}$ & $\mathbf{2 0 0 2}$ & $\mathbf{2 0 0 3}$ & $\mathbf{2 0 0 4}$ & $\mathbf{2 0 0 5}$ & $\mathbf{2 0 0 6}$ \\
\hline Processing & 90.4 & 91.0 & 90.7 & 89.2 & 87.9 & 87.2 & 83.7 \\
\hline Ordinary & 7.5 & 6.9 & 7.4 & 8.2 & 8.7 & 9.4 & 12.6 \\
\hline Other & 2.1 & 2.1 & 1.9 & 2.6 & 3.5 & 3.4 & 3.7 \\
\hline
\end{tabular}

Source: Chinese Customs Trade Statistics (CCTS), 2000-2007, authors' own calculations.

China's ICT exports are heavily concentrated in processing trade, which accounts for 90 per cent of China's ICT exports. Thus, China's ICT exports are largely due to the international segmentation of production processes. China imports parts and components of ICT products, which are incorporated in processed exports. China's ICT exports, therefore, can be explained by their high import content. In fact, it has been shown that the share of domestic content of China's manufactured exports was about 50 per cent, and relatively sophisticated products, such as electronic devices, have low domestically produced contents (about 30 per cent or less) (Koopman et al. 2012).

Furthermore, Chinese authorities have been actively promoting the level of technology in China's export structure through tax and other policy incentives. A particular manifestation of these incentives is the proliferation of special economic zones (SEZs), economic and technological development zones, hightech industrial zones, export processing zones and free trade zones around the world. In order to analyse policy effects on ICT exports, Table 17.2 reports the export ratio of different policy zones:

Table 17.2 The ratio of different policy zones in China's ICT export (\%)

\begin{tabular}{l|r|r|r|r|r|r|r}
\hline Policy zone & $\mathbf{2 0 0 0}$ & $\mathbf{2 0 0 1}$ & $\mathbf{2 0 0 2}$ & $\mathbf{2 0 0 3}$ & $\mathbf{2 0 0 4}$ & $\mathbf{2 0 0 5}$ & $\mathbf{2 0 0 6}$ \\
\hline 1 & 11.0 & 10.6 & 9.2 & 8.5 & 6.8 & 6.5 & 6.4 \\
\hline 2 & 11.3 & 13.1 & 13.0 & 14.2 & 17.6 & 20.7 & 19.8 \\
\hline 3 & 6.3 & 7.1 & 7.7 & 8.9 & 9.5 & 10.2 & 8.9 \\
\hline 4 & 7.2 & 7.1 & 8.1 & 7.6 & 8.0 & 6.7 & 6.4 \\
\hline 5 & 0.0 & 0.7 & 2.4 & 3.5 & 4.0 & 5.6 & 4.7 \\
\hline 6 & 64.2 & 61.4 & 59.7 & 57.3 & 54.1 & 50.2 & 53.8 \\
\hline
\end{tabular}

Note: Policy zone 1 stands for special economic zones. Zones 2 to 5 stand for economic and technological development zones, high-tech industrial zone, export processing zones and free trade zones respectively, 6 stands for others. The policy zone accounts for nearly half of China's ICT exports. Government policies, therefore, do effect China's export structure.

Source: Chinese Customs Trade Statistics (CCTS), 2000-2007, authors' calculations.

The above analysis shows that the extent of China's ICT exports is overestimated if we do not consider the role played by foreign affiliates through international segmentation of production processes. Government policy also plays an important role in enhancing China's exports. There is, however, another 
important difference between China's ICT exports and those of developed countries. As Schott (2004) points out, current international trade specialises within product rather than across product. Although China is responsible for nearly one-third of world ICT exports, the quality of China's ICT exports have been lower than those exported by developed countries. Following David Hummels and Peter Klenow (2005), we disaggregate the share of China's ICT exports in the world market into three margins: extensive margin, quantity and quality. Table 17.3 reports the main decomposing results:

Table 17.3 The extensive margin, quantity and quality in China's ICT export ratio

\begin{tabular}{l|l|c|c|c}
\hline Year & Ratio & Extensive margin & Quantity & Quality \\
\hline 1995 & 0.030 & 0.786 & 0.071 & 0.544 \\
\hline 1996 & 0.035 & 0.818 & 0.085 & 0.498 \\
\hline 1997 & 0.037 & 0.827 & 0.088 & 0.508 \\
\hline 1998 & 0.043 & 0.827 & 0.100 & 0.514 \\
\hline 1999 & 0.046 & 0.842 & 0.109 & 0.505 \\
\hline 2000 & 0.056 & 0.841 & 0.111 & 0.603 \\
\hline 2001 & 0.072 & 0.848 & 0.123 & 0.685 \\
\hline 2002 & 0.104 & 0.848 & 0.159 & 0.775 \\
\hline 2003 & 0.135 & 0.848 & 0.234 & 0.679 \\
\hline 2004 & 0.161 & 0.853 & 0.271 & 0.696 \\
\hline 2005 & 0.193 & 0.918 & 0.232 & 0.906 \\
\hline 2006 & 0.216 & 0.920 & 0.241 & 0.973 \\
\hline 2007 & 0.243 & 0.925 & 0.285 & 0.923 \\
\hline 2008 & 0.261 & 0.911 & 0.300 & 0.954 \\
\hline 2009 & 0.282 & 0.896 & 0.330 & 0.951 \\
\hline 2010 & 0.301 & 0.894 & 0.373 & 0.903 \\
\hline Growth rate (\%) & 229.3 & 12.9 & 165.7 & 50.7 \\
\hline
\end{tabular}

Source: CEPII BACI Database, authors' calculation.

For the quality index, the number is smaller than one, which means that China's ICT export quality is lower than the world average level. From the dynamic view, the growth rate of the ratio is 229.3 per cent, with an extensive margin growth rate of 12.9 per cent; a quantity growth rate of 165.7 per cent and a quality growth rate of 50.7 per cent. The results, therefore, show that China's ICT export growth is mainly driven by increases in quantity, which accounts for 72.3 per cent of China's ICT export growth, with the contribution made by quality accounting for only 22.1 per cent of China's ICT export growth. 
To summarise the above analysis, China's ICT export value is increasing, which is driven by the growth in quantity. The quality of these exports, however, is lower than the world average.

\section{Empirical Strategy and Data}

The modelling approach adopted here explains not only the fast growth of the ratio and quantity, but also the low growth rate of quality. Export value, quantity and quality form the dependent variables in the model estimation. We consider several categories of determinants (Xu \& Lu 2009, Wang \& Wei 2008), including the use of processing trade; the development of central and local government policy to promote these sectors; the role of foreign affiliates; and, the characteristics of the trading partners, such as their levels of GDP and physical distance from China. Formally, the econometric specification is given by the following equations:

$\operatorname{lnx}_{i j k t}=\alpha+\beta_{1} f d i_{i t}+\beta_{2}$ process $_{i j k t}+\beta_{3}$ policy $_{i j k t}+\beta_{4} \ln g d p_{j t}+\beta_{5} \ln d i s t_{j t}+\lambda_{k}+\lambda_{t}+\varepsilon_{i j k t}$

where $\ln x_{i j k t}$ is the $\log$ of firm $i$ 's export index to country $j$ in product $k$ at year $t$. We define the index of export by using three different dimensions, they are value, quantity and quality, with quality measured by the unit value. $f d i_{i t}$ is a dummy, if firm $i$ in year $t$ is a wholly foreign owned firm or joint venture, it is 1 ; if firm $i$ in year $t$ is a Chinese firm, then it is 0 . process $s_{i j k t}$ is also a dummy, indicating whether the trade involved is processing trade according to the customs regime. policy $y_{i j k t}$ is a dummy variable to show whether the firms have received some of kinds of policy promotion provided by the governments. $\ln g d p_{j t}$ is the log of the gross domestic product of the importing country $j$ in year $t, \ln$ dist $_{j t}$ is the distance between country $j$ and China. $\lambda_{k}, \lambda_{t}$ are product and year fixed effects. $\varepsilon_{i j k t}$ is the error term as normally defined.

In order to check the robustness of the regression results, we define the indexes of $f d i$, process and policy in a more detailed way. We can further classify $f d i$ into two subgroups, wfof and $j v$, where $w f o f$ standing for the wholly foreign owned firms and jv representing joint ventures. For the index process, we also have two detailed indexes, process 1 and process 2 , where process 1 means 'processing and assembling' and process 2 means 'process with imported materials'. For the index of policy, we have five different policy zones, policyl being 'special economy zone', policy2 being 'economic and technological development zones', policy3 being 'high-technology industrial zone', policy4 being 'export processing zones', policy5 being 'free trade zone'. So we have the following equation for robustness check: 


$$
\begin{aligned}
& \operatorname{lnx}_{i j k t}=\alpha+\beta_{11} w f o f_{i t}+\beta_{12} j v_{i t}+\sum_{l=1}^{2} \beta_{2 l} \text { process }_{l, i j k t}+\sum_{m=1}^{5} \beta_{3 m} \text { policy }_{m, i j k t} \\
& +\beta_{4} \ln g d p_{j t}+\beta_{5} \ln d i s t_{j t}+\lambda_{k}+\lambda_{t}+\varepsilon_{i j k t}
\end{aligned}
$$

It is argued that foreign firms have certain inherent disadvantages as compared with indigenous firms, such as communication costs, language and cultural barriers, and limited familiarity with local environments. Foreign firms, therefore, must possess certain advantages over local firms in order to compete in the host country market. One of the advantages that foreign firms have in investing in the host country is possessing more advanced technology, which local firms do not have. Furthermore, the literature on FDI also suggests that ownership structure is a key determinant of the level of technology chosen by foreign firms while investing. According to the ownership-locationinternalisation paradigm, WFOF have the advantage of internalising superior technologies or knowhow within the firm, and JV rely more on the relationship with local partners to be more competitive in local markets. So, foreign firms should consider the trade-off between securing a better position in the market and allowing local partners to share with them the technologies and profits. The foreign investors with more advanced technologies will therefore prefer WFOFs to JVs. To summarise, we expect that the FDI will not only increase China's ICT export volume, but also upgrade the quality of China's ICT exports, and this effect is more apparent for WFOFs.

As we have discussed, processing trade plays a dominant role in China's ICT exports. As Lee Branstetter and Nicholas Lardy (2006) point out, China is able to export huge quantities of ICT products only because it imports most of the value-added parts and components embodied in the exports. Estimates of the share of foreign content in China's high-technology product export are up to 80 per cent (Koopman et al. 2012). We expect, therefore, that processing trade will increase both China's ICT export value and quantity.

Policy is an important factor in determining a country's involvement in the international splitting up of the value-added chain, which further upgrades countries' technology and promotes ICT exports. China has followed a dualtrack trade policy, by imposing customs tariffs to protect domestic industries, while offering tariff exemptions on imported inputs for export production. These policies help increase China's ICT exports. Apart from these policies, Chinese authorities have also used other policy instruments to promote exports. A particular manifestation of these incentives is the proliferation of special policy zones, including special economic, economic and technological development, high-technology industrial, export processing and free trade zones. We expect, 
therefore, that government policy through various kinds of instruments will increase China's ICT exports, and some policy may also be conducive to upgrading China's ICT quality.

Finally, the characteristics of the importing country may also affect China's ICT exports at the firm level. As in the traditional gravity model, larger GDP and shorter distances should lead to larger export value and quantity. The quality of firm's exports should increase with distance (Hummels and Skiba 2004). We expect, therefore, that the importing countries' GDP positively correlates with ICT's export value and quantity, and their distance positively correlates with quality and negatively correlates with quantity and value. Before reporting the regression results, Table 17.4 provides the variable descriptions and summary statistics.

Table 17.4 Variable descriptions and summary statistics

\begin{tabular}{l|l|r|r|c}
\hline Variable & Description & Observation & Mean & $\begin{array}{c}\text { Standard } \\
\text { deviation }\end{array}$ \\
\hline Inv & Log of export value & 973,742 & 9.22 & 2.65 \\
\hline Inp & Log of export quality & 973,742 & 1.75 & 2.63 \\
\hline Inq & Log of export quantity & 973,742 & 7.47 & 3.39 \\
\hline fdi & Dummy for foreign firm & 973,742 & 0.41 & 0.49 \\
\hline process & Dummy for processing trade & 973,742 & 0.31 & 0.46 \\
\hline policy & Dummy for policy zone & 973,742 & 0.25 & 0.43 \\
\hline wfof & Dummy for wholly foreign-owned firm & 973,742 & 0.28 & 0.45 \\
\hline jv & Dummy for joint venture & 973,742 & 0.13 & 0.34 \\
\hline process1 & Dummy for processing and assembling & 973,742 & 0.23 & 0.42 \\
\hline process2 & Dummy for processing with imported & 973,742 & 0.08 & 0.27 \\
\hline policy1 & Dummy for special economic zone & 973,742 & 0.09 & 0.29 \\
\hline policy2 & Dummy for economic and technological & 973,742 & 0.07 & 0.25 \\
\hline policy3 & Dummy for high-technology zone & 973,742 & 0.04 & 0.20 \\
\hline policy4 & Dummy for export processing zone & 973,742 & 0.05 & 0.21 \\
\hline policy5 & Dummy for free trade zone & 973,742 & 0.01 & 0.09 \\
\hline Ingdp & Log of importer's GDP & 973,329 & 20.07 & 1.53 \\
\hline & Log of distance between China and & 963,358 & 8.49 & 0.77 \\
\hline & importer & & & \\
\hline & Deve & & & \\
\hline
\end{tabular}

Source: Authors' definitions and descriptions. 


\section{Estimation Results}

\section{Value Regressions}

Table 17.5 reports the estimation results from the basic regressions on value. The estimated coefficients on $f d i$ are both positive and statistically significant in regressions 5.1 and 5.4; the estimated coefficients on process are both positive and statistically significant in regressions 5.2 and 5.4; the estimated coefficients on policy are both positive and statistically significant in regressions 5.3 and 5.4. These results show that foreign firms, processing trade and government policy all have positive and statistically significant effects on upgrading China's ICT exports. The estimated coefficients on $\operatorname{lng} d p$ are all positive and statistically significant in the regressions 5.1 5.4, and the estimated coefficients on lndist are all negative and statistically significant in the regressions 5.1 5.4. All the regression results support the theoretical analysis and predictions reviewed in the previous section.

A further observation finds that the estimated coefficient on $f d i$ becomes much smaller in regression 5.4 than in regression 5.1, when we take into account the effects of processing trade. Similarly, the estimated coefficient on policy becomes much larger in regression 5.4 than in regression 5.2, when we take account of the effects of processing trade. The estimated coefficients on process, however, are nearly the same in regressions 5.2 and 5.4. These results imply that processing trade is the most important and robust factor that promotes China's ICT export. Foreign firms can promote China's ICT exports, and the effect of this will decrease when taking account of the role of processing trade. This means that foreign firms promote China's ICT exports mainly through processing trade. Following the same logic, the effects of policy on promoting China's ICT are underestimated by ignoring the influence of processing trade in determining China's ICT exports. 
China: A New Model for Growth and Development

Table 17.5 Basic estimation results for dependent variable Inv

\begin{tabular}{|c|c|c|c|c|}
\hline & $(5.1)$ & $(5.2)$ & $(5.3)$ & $(5.4)$ \\
\hline \multirow[t]{2}{*}{ Fdi } & $0.801 * * *$ & & & $0.132 * * *$ \\
\hline & $(146.862)$ & & & $(21.710)$ \\
\hline \multirow[t]{2}{*}{ process } & & $1.617 * * *$ & & $1.555 * * *$ \\
\hline & & (280.992) & & $(238.022)$ \\
\hline \multirow[t]{2}{*}{ policy } & & & $0.030 * * *$ & $0.077 * * *$ \\
\hline & & & $(4.944)$ & $(13.112)$ \\
\hline \multirow[t]{2}{*}{ Ingdp } & $0.194 * * *$ & $0.181 * * *$ & $0.226 * * *$ & $0.176 * * *$ \\
\hline & $(114.645)$ & (110.409) & (133.018) & $(107.064)$ \\
\hline \multirow[t]{2}{*}{ Indist } & $-0.169 * * *$ & $-0.174 * * *$ & $-0.197 * * *$ & $-0.170 * * *$ \\
\hline & $(-49.629)$ & $(-52.717)$ & $(-57.390)$ & $(-51.507)$ \\
\hline Year fixed effects & yes & yes & yes & yes \\
\hline Product fixed effects & yes & yes & yes & yes \\
\hline$N$ & 963,358 & 963,358 & 963,358 & 963,358 \\
\hline$R 2$ & 0.127 & 0.175 & 0.107 & 0.176 \\
\hline
\end{tabular}

Note: The dependent variable is log value. Absolute values of t statistics are in parentheses. ${ }^{*}$ significant at $10 \% ;{ }^{* *}$ significant at $5 \% ;{ }^{* * *}$ significant at $1 \%$.

Source: Authors' estimations.

Table 17.6 reports the robustness of the regression results for value regression. In regressions 6.1 and 6.4, we break fdi into $w f o f$ and $j v$. The estimated coefficients on $j v$ are both positive and statistically significant, but it becomes smaller in regression 6.4, which implies that the $j v$ firms' effect on China's ICT export is mainly through processing trade. So the results on $j v$ confirms our discussion in Table 17.5. In regression 6.1, the estimated coefficient on wfof is positive and statistically significant, but in regression 6.4 it becomes statistically indifferent from zero, which also confirms and strengthens the analysis based on the results in Table 17.5. In fact, 92.4 per cent of WFOF's ICT exports are finished by processing trade.

In regressions 6.2 and 6.4, we distinguish two kinds of processing trade, where process 1 means the processing and assembling and process 2 means processing with imported materials. The coefficients on the two variables are all positive and statistically significant, having nearly the same magnitudes in regressions 6.2 and 6.4. We conclude, therefore, that processing trade has the most robust effects on China's ICT export, whichever kind of processing trade it is. 
Table 17.6 Robustness check for dependent variable Inv

\begin{tabular}{|c|c|c|c|c|}
\hline & (6.1) & (6.2) & (6.3) & (6.4) \\
\hline \multirow[t]{2}{*}{ wfof } & $0.815 * * *$ & & & 0.011 \\
\hline & $(132.415)$ & & & $(1.419)$ \\
\hline \multirow[t]{2}{*}{ jv } & $0.773 * * *$ & & & $0.272 * * *$ \\
\hline & (96.981) & & & (32.092) \\
\hline \multirow[t]{2}{*}{ process 1} & & $1.638 * * *$ & & $1.618 * * *$ \\
\hline & & $(260.092)$ & & $(203.003)$ \\
\hline \multirow[t]{2}{*}{ process2 } & & $1.556 * * *$ & & $1.592 * * *$ \\
\hline & & $(160.883)$ & & $(163.369)$ \\
\hline \multirow[t]{2}{*}{ policy 1} & & & $-0.221 * * *$ & -0.008 \\
\hline & & & $(-24.474)$ & $(-0.907)$ \\
\hline \multirow[t]{2}{*}{ policy2 } & & & $0.222 * * *$ & $0.232 * * *$ \\
\hline & & & $(20.904)$ & $(22.593)$ \\
\hline \multirow[t]{2}{*}{ policy3 } & & & $0.387 * * *$ & $0.168 * * *$ \\
\hline & & & (29.833) & $(13.217)$ \\
\hline \multirow[t]{2}{*}{ policy 4} & & & $-0.064 * * *$ & $0.130 * * *$ \\
\hline & & & $(-5.136)$ & (10.510) \\
\hline \multirow[t]{2}{*}{ policy5 } & & & $0.165 * * *$ & $-0.773 * * *$ \\
\hline & & & $(5.507)$ & $(-26.561)$ \\
\hline \multirow[t]{2}{*}{ Ingdp } & $0.194 * * *$ & $0.181 * * *$ & $0.224 * * *$ & $0.177 * * *$ \\
\hline & $(114.556)$ & $(110.402)$ & $(131.914)$ & $(107.210)$ \\
\hline \multirow[t]{2}{*}{ Indist } & $-0.169 * * *$ & $-0.174 * * *$ & $-0.201 * * *$ & $-0.174 * * *$ \\
\hline & $(-49.504)$ & $(-52.756)$ & $(-58.407)$ & $(-52.730)$ \\
\hline Year fixed effects & yes & yes & yes & yes \\
\hline Product fixed effects & yes & yes & yes & yes \\
\hline$N$ & 963,358 & 963,358 & 963,358 & 963,358 \\
\hline$R 2$ & 0.127 & 0.175 & 0.109 & 0.177 \\
\hline
\end{tabular}

Note: The dependent variable is log value. Absolute values of $\mathrm{t}$ statistics are in parentheses. * significant at $10 \% ;{ }^{* *}$ significant at $5 \% ;{ }^{* * *}$ significant at $1 \%$.

Source: Authors' estimations.

In regressions 6.3 and 6.4, we break policy into five different policy zones, as defined in Table 17.4. We find that only the estimated coefficients on Policy 2 and Policy 3 are positive and statistically significant. Policy 2 is the economic and technological development zones and Policy 3 is high-technology industrial zones. Both zones are aimed at attracting FDIs with more advanced technologies, thereby upgrading the production and trade structures for firms operating in these zones. Policy 1 is the special economic zone, the aim of which is more complex and not only confined to technology upgrading. Policy 4 is the export processing zone, the effect of which may be embodied in the variable of processing trade. Policy 5 is the free trade zone, the aim of which is to enlarge trade volume using whatever technology levels that the trading products may contain. 
To summarise the discussion for value regression, we found that processing trade is the most robust and important force in promoting China's ICT exports. Only joint ventures and some kinds of special policy zones have robust and positive effects on China's ICT export.

\section{Quantity Regressions}

Table 17.7 reports the estimation results of the basic regressions for the quantity. The estimated coefficient on $f d i$ in 7.1 is positive and statistically significant but turns negative and also statistically significant in 7.4, when we consider the processing trade effects. The estimated coefficients on policy are both negative and statistically significant in regressions 7.3 and 7.4. The estimated coefficients on process are both positive and statistically significant in regressions 7.2 and 7.4. So we can conclude that foreign firms and government policy tend to decrease the ICT export quantity, while processing trade tends to increase the ICT export quantity.

The estimated coefficients on lngdp are all positive and statistically significant in regressions 7.1-7.4. The estimated coefficients on lndist are all negative and statistically significant in regressions 7.1-7.4. These results are similar to the results in the regressions for the value.

Table 17.7 Basic estimation results for dependent variable Inq

\begin{tabular}{|c|c|c|c|c|}
\hline & $(7.1)$ & $(7.2)$ & (7.3) & (7.4) \\
\hline \multirow[t]{2}{*}{$f d i$} & $0.032 * * *$ & & & $-0.647 * * *$ \\
\hline & $(5.052)$ & & & $(-93.225)$ \\
\hline \multirow[t]{2}{*}{ process } & & $1.444 * * *$ & & $1.747 * * *$ \\
\hline & & (217.915) & & $(234.177)$ \\
\hline \multirow[t]{2}{*}{ policy } & & & $-0.634 * * *$ & $-0.453 * * *$ \\
\hline & & & $(-93.502)$ & $(-67.361)$ \\
\hline \multirow[t]{2}{*}{$\operatorname{lng} d p$} & $0.166 * * *$ & $0.127 * * *$ & $0.176 * * *$ & $0.151 * * *$ \\
\hline & $(85.566)$ & $(67.171)$ & (91.809) & $(80.064)$ \\
\hline \multirow[t]{2}{*}{ Indist } & $-0.316 * * *$ & $-0.296 * * *$ & $-0.317^{* * *}$ & $-0.315^{* * *}$ \\
\hline & $(-80.922)$ & $(-77.889)$ & $(-81.851)$ & $(-83.453)$ \\
\hline Year fixed effects & yes & yes & yes & yes \\
\hline Product fixed effects & yes & yes & yes & yes \\
\hline$N$ & 963,358 & 963,358 & 963,358 & 963,358 \\
\hline$R 2$ & 0.298 & 0.331 & 0.304 & 0.342 \\
\hline
\end{tabular}

Note: The dependent variable is log quantity. Absolute values of $\mathrm{t}$ statistics are in parentheses. * significant at $10 \% ;{ }^{* *}$ significant at $5 \% ;{ }^{* * *}$ significant at $1 \%$.

Source: Authors' estimations. 
Table 17.8 Robustness check for dependent variable Inq

\begin{tabular}{|c|c|c|c|c|}
\hline & (8.1) & (8.2) & (8.3) & (8.4) \\
\hline \multirow[t]{2}{*}{ wfof } & $0.055 * * *$ & & & $-0.664 * * *$ \\
\hline & $(7.806)$ & & & $(-75.468)$ \\
\hline \multirow[t]{2}{*}{ jv } & $-0.016 *$ & & & $-0.429 * * *$ \\
\hline & $(-1.784)$ & & & $(-44.374)$ \\
\hline \multirow[t]{2}{*}{ process 1} & & $1.296 * * *$ & & $1.781 * * *$ \\
\hline & & $(179.078)$ & & (195.875) \\
\hline \multirow[t]{2}{*}{ process2 } & & $1.894 * * *$ & & $1.830 * * *$ \\
\hline & & (170.329) & & (164.605) \\
\hline \multirow[t]{2}{*}{ policy 1} & & & $-0.294 * * *$ & $-0.115 * * *$ \\
\hline & & & $(-28.854)$ & $(-11.525)$ \\
\hline \multirow[t]{2}{*}{ policy2 } & & & $-0.678 * * *$ & $-0.548 * * *$ \\
\hline & & & $(-56.584)$ & $(-46.775)$ \\
\hline \multirow[t]{2}{*}{ policy3 } & & & $-0.802 * * *$ & $-0.762 * * *$ \\
\hline & & & $(-54.722)$ & $(-52.634)$ \\
\hline \multirow[t]{2}{*}{ policy 4} & & & $-1.065 * * *$ & $-0.569 * * *$ \\
\hline & & & $(-75.980)$ & $(-40.295)$ \\
\hline \multirow[t]{2}{*}{ policy 5} & & & $-1.036 * * *$ & $-1.709 * * *$ \\
\hline & & & $(-30.709)$ & $(-51.495)$ \\
\hline \multirow[t]{2}{*}{$\operatorname{lngdp}$} & $0.166 * * *$ & $0.127 * * *$ & $0.177 * * *$ & $0.150 * * *$ \\
\hline & (85.445) & (67.329) & (92.544) & (79.876) \\
\hline \multirow[t]{2}{*}{ Indist } & $-0.315 * * *$ & $-0.295 * * *$ & $-0.319 * * *$ & $-0.313^{* * *}$ \\
\hline & $(-80.735)$ & $(-77.748)$ & $(-82.330)$ & $(-83.023)$ \\
\hline Year fixed effects & yes & yes & yes & yes \\
\hline Product fixed effects & yes & yes & yes & yes \\
\hline$N$ & 963,358 & 963,358 & 963,358 & 963,358 \\
\hline$R 2$ & 0.298 & 0.332 & 0.306 & 0.344 \\
\hline
\end{tabular}

Note: The dependent variable is log quantity. Absolute values of $t$ statistics are in parentheses. ${ }^{*}$ significant at $10 \% ;{ }^{* *}$ significant at $5 \% ;{ }^{* * *}$ significant at $1 \%$.

Source: Authors' estimations.

Table 17.8 provides the robustness check results for estimating quantity regressions. Based on these results, we can conclude that both WFOFs and JVs have negative effects on export quantity, when taking into account processing trade. Both processing and assembling, with imported materials, have positive effects on export quantity. All the five types of policy zones have negative effects on export quantity.

To summarise the results reported in tables 17.7 and 17.8, we found that processing trade can promote ICT export quantity, but FDI and government policy lead to smaller export quantity. We found, however, that policy can promote export value, which requires further analysis of the quality regressions. 


\section{Quality Regressions}

Table 17.9 reports the basic estimation results for quality regression. The estimated coefficients on $f d i$ are positive and statistically significant in 9.1 and 9.4, and are nearly the same in magnitudes. The estimated coefficients on policy are positive and statistically significant in 9.1 and 9.4, and are also the same in magnitude. Foreign firms and government policy, therefore, tend to upgrade the quality of China's ICT exports, and this finding is robust, even taking into account processing trade.

The estimated coefficient on process, however, is not robust. It is positive and statistically significant in 9.2, but it turns negative and statistically significant in 9.4, when taking into account $f d i$ and the role of government policy. So, processing trade may degrade the quality of China's ICT exports, but it promotes value and quantity of China's ICT export as found in the previous regression on quantities.

The estimated coefficients on $\operatorname{lng} d p$ are positive and statistically significant in regressions 9.1-9.4. The larger the gross domestic product level is, the more demands for ICT product, the more fierce competition firms face. Only those firms, therefore, who can produce high quality products can export to these markets. The estimated coefficient on Indist are positive and statistically significant in regressions 9.1-9.4, so the longer the distance, the higher the quality (Hummels and Skiba 2004).

Table 17.9 Basic estimation results for dependent variable Inp

\begin{tabular}{|c|c|c|c|c|}
\hline & (9.1) & (9.2) & (9.3) & (9.4) \\
\hline \multirow[t]{2}{*}{$f d i$} & $0.770 * * *$ & & & $0.779 * * *$ \\
\hline & (193.688) & & & $(172.535)$ \\
\hline \multirow[t]{2}{*}{ process } & & $0.174 * * *$ & & $-0.192 * * *$ \\
\hline & & (39.580) & & $(-39.520)$ \\
\hline \multirow[t]{2}{*}{ policy } & & & $0.664 * * *$ & $0.530 * * *$ \\
\hline & & & $(152.210)$ & $(121.200)$ \\
\hline \multirow[t]{2}{*}{ Ingdp } & $0.028 * * *$ & $0.054 * * *$ & $0.050 * * *$ & $0.026 * * *$ \\
\hline & (22.778) & (43.383) & $(40.567)$ & (21.069) \\
\hline \multirow[t]{2}{*}{ Indist } & $0.147 * * *$ & $0.122 * * *$ & $0.120 * * *$ & $0.145 * *$ \\
\hline & $(59.180)$ & (48.383) & $(48.181)$ & (58.938) \\
\hline Year fixed effects & yes & yes & yes & yes \\
\hline Product fixed effects & yes & yes & yes & yes \\
\hline$N$ & 963,358 & 963,358 & 963,358 & 963,358 \\
\hline$R 2$ & 0.530 & 0.512 & 0.523 & 0.538 \\
\hline
\end{tabular}

Notes: The dependent variable is log quality. Absolute values of $t$ statistics are in parentheses. ${ }^{*}$ significant at $10 \% ;{ }^{* *}$ significant at $5 \% ;{ }^{* * *}$ significant at $1 \%$. 
Table 17.10 provides the robustness check results for quality regressions. We can conclude that both WFOFs and JVs have positive effects on export quality. Both processing and assembling, and processing with imported materials have negative effects on export quantity. The five types of policy zones have positive effects on export quantity. The larger the GDP level, the further the distance it is, the higher the level of export quality. All these results are supportive of the basic regression results reported in Table 17.9.

Table 17.10 Robustness check for dependent variable Inp

\begin{tabular}{|c|c|c|c|c|}
\hline & $(10.1)$ & $(10.2)$ & $(10.3)$ & $(10.4)$ \\
\hline \multirow[t]{2}{*}{ wfof } & $0.760 * * *$ & & & $0.675 * * *$ \\
\hline & (169.519) & & & $(118.179)$ \\
\hline \multirow[t]{2}{*}{$j v$} & $0.789 * * *$ & & & $0.701 * * *$ \\
\hline & $(135.958)$ & & & $(111.700)$ \\
\hline \multirow[t]{2}{*}{ process 1} & & $0.342 * * *$ & & $-0.163 * * *$ \\
\hline & & (71.382) & & $(-27.604)$ \\
\hline \multirow[t]{2}{*}{ process 2} & & $-0.338 * * *$ & & $-0.238 * * *$ \\
\hline & & $(-45.897)$ & & $(-32.956)$ \\
\hline \multirow[t]{2}{*}{ policy 1} & & & $0.073 * * *$ & $0.107 * * *$ \\
\hline & & & $(11.204)$ & $(16.530)$ \\
\hline \multirow[t]{2}{*}{ policy 2} & & & $0.900 * * *$ & $0.780 * * *$ \\
\hline & & & (117.594) & $(102.571)$ \\
\hline \multirow[t]{2}{*}{ policy3 } & & & $1.189 * * *$ & $0.929 * * *$ \\
\hline & & & (127.069) & (98.934) \\
\hline \multirow[t]{2}{*}{ policy 4} & & & $1.001 * * *$ & $0.699 * * *$ \\
\hline & & & (111.818) & (76.271) \\
\hline \multirow[t]{2}{*}{ policy5 } & & & $1.201 * * *$ & $0.936 * * *$ \\
\hline & & & $(55.718)$ & $(43.460)$ \\
\hline \multirow[t]{2}{*}{ Ingdp } & $0.028 * * *$ & $0.054 * * *$ & $0.047 * * *$ & $0.027 * * *$ \\
\hline & $(22.849)$ & $(43.431)$ & $(38.200)$ & $(21.732)$ \\
\hline \multirow[t]{2}{*}{ Indist } & $0.146 * * *$ & $0.121 * * *$ & $0.118 * * *$ & $0.139 * * *$ \\
\hline & (59.056) & $(48.154)$ & $(47.826)$ & $(56.691)$ \\
\hline Year fixed effects & yes & yes & yes & yes \\
\hline Product fixed effects & yes & yes & yes & yes \\
\hline$N$ & 963,358 & 963,358 & 963,358 & 963,358 \\
\hline$R 2$ & 0.530 & 0.516 & 0.531 & 0.542 \\
\hline
\end{tabular}

Notes: The dependent variable is log quality. Absolute values of t statistics are in parentheses. * significant at $10 \% ;{ }^{* *}$ significant at $5 \% ;{ }^{* * *}$ significant at $1 \%$.

Source: Authors' estimations. 
We can summarise the regression results reported in Tables 17.5 to 17.10 as follows. FDI, processing trade and government policy are important key determinants of China's ICT export pattern. FDI can upgrade export quality, but decrease export quantity and value. Processing trade promotes export value through lower quality and larger quantity. Government policy increases value and quality, but decreases export value. These results suggest that, in order to further increase the export quantities of ICT products and, at the same time, to increase the export qualities of these products, China may consider applying different policy instruments for addressing different objectives. For example, if export quality is a concern, the government should do more in attracting FDI with more advanced technologies, and in further developing high-tech zones.

\section{Conclusion}

In this chapter we focus on the quantity and quality of China's ICT exports and its determinants to find out the key characteristics associated with China's ICT exports. We arrived at the following conclusions: China's ICT export is mainly driven by high quantity and low quality production; and, FDI, processing trade and government policies are the main determinants for China's ICT export growth. FDI, processing trade and government policies, however, have a different impact on quantity and quality. Processing trade increases quantity but decreases quality, while FDI and government policy have the opposite impact. How to upgrade quality and increase quantity simultaneously, therefore, is a challenge for Chinese central and local governments in their efforts to restructure the export sectors and move production towards producing high value-added and high quality products, while increasing the level of employment.

In this sense, the pattern of high quantity and low quality production and export will have an important influence on China' future growth. As quantity contributes significantly to China's ICT exports, it means China should continue to employ a large labour force to produce the export quantity; the quantitydriven export growth pattern, therefore, is good for employment. Considering that China is still relatively abundant in labour supplies, the quantity-driven growth pattern is consistent with China's comparative advantage and quantity, therefore, remains a policy option for the time being. Quantity-driven growth patterns, however, consume more natural resources and tend to lead to more pollution and damage to the environment, which is harmful to sustainable economic growth. As product quality is important for maintaining export competitiveness, and leads to more endogenously determined economic growth, how to upgrade the export quality is important for China's sustainable export and economic growth. Importantly, China is undergoing a fundamental change in its demographic structure leading to the slow growth of its labour force, 
apart from ageing, with rising wage levels (Cai 2013). This will add further pressure for the Chinese Government to optimise its economic structure and move towards producing more high-quality products. As a result, one would expect that China's export sector will be transformed from the quantity-driven to an extensively margin-driven and quality-driven one. This transformation is consistent with the new growth strategy adopted by the Chinese Government in confronting the new challenges for future growth.

\section{References}

Branstetter, L. \& Lardy, N., 2006, 'China's Embrace of Globalization', NBER Working Paper, No. 12373.

Cai, Fang, 2013, 'Can China Avert the Middle Income Trap?', working paper, Chinese Academy of Social Sciences, Beijing.

Feenstra, Robert C., 1994, 'New product varieties and the measurement of international prices', American Economic Review, vol. 84. no. 1, pp. 157-77.

General Administration of Customs of China, Chinese Customs Trade Statistics (CCTS), 2000-2007.

Greenaway, D., Morgan, C.W. \& Wright, P.W., 1999, 'Export Composition, Exports and Growth', Journal of International Trade and Economic Development, vol. 8, pp. 41-52.

Hausmann, R., Hwang, J. \& Rodrik, D., 2007, 'What you Export Matters', Journal of Economic Growth, vol. 12, no. 1, pp. 1-25.

Hummels, D. \& Klenow, P.J., 2005, 'The Variety and Quality of a Nation's Exports', American Economic Review, vol. 95, pp. 704-19.

Hummels, D. \& Skiba, A., 2004, 'Shipping the Good Apples Out? An Empirical Confirmation of the Alchian-Allen Conjecture', Journal of Political Economy, vol. 112, no. 6, pp. 1384-402.

Jorgenson, D.W., Ho, M.S. \& Stiroh, K.J., 2008, 'A Retrospective Look at the U.S. Productivity Growth Resurgence', Journal of Economic Perspectives, vol. 22, no. 1, pp. 3-24.

Koopman, R., Wang, Zhi \& Wei, Shang-Jin, 2012, ‘Estimating Domestic Content in Exports When Processing Trade is Pervasive', Journal of Development Economics, vol. 99, pp. 178-89. 
National Bureau of Statistics of China, China's Annual Survey of Industrial Firms (CASIF), 1998-2007.

Onlier, S. \& Sichel, D., 2000, 'The Resurgence of Growth in the Late 1990s: Is Information Technology the Story', Journal of Economic Perspective, vol. 14, no. 4, pp. 3-22.

Rodrik, D., 2006, 'What is So Special about China's Export', China \& World Economy, vol. 14, no. 5, pp. 1-19.

Schott, P., 2004, 'Across-Product versus Within-Product Specialization in International Trade', Quarterly Journal of Economics, vol. 119, no. 2, pp. 647-78.

Simon, J.P., 2011, 'The ICT Landscape in BRICS Countries: Brazil, India and China', European Commission Joint Research Centre Institute for Prospective Technological Studies.

UNCTAD, 2011, 'Measuring the Impacts of Information and Communication Technology for Development', Current Studies on Science, Technology and Innovation, No. 3.

Wang, Z. \& Wei, S.J., 2008, 'What Accounts for the Rising Sophistication of China's Exports?', NBER Working Paper, No. 13771.

Xu, B. \& Lu, J.Y., 2009, 'Foreign Direct Investment, Processing Trade and the Sophistication of China's Export', China Economic Review, vol. 20, pp. 425-39.

\section{Appendix: The Disaggregating Procedure for Table 17.3}

We follow the method of Hummels and Klenow (2005) to decompose trade ratio to get Table 17.3.

Considering China and world's ITC export, supposing the exporting product sets are $\Omega_{C}$ and $\Omega_{W}$, and the overlapped exporting products set is $\Omega$, that is $\Omega=\Omega_{C} \cap \Omega_{W}$, then the ratio of export between China and world can be expressed as equation (1)

$$
R=\frac{\sum_{i \in \Omega_{C}} v_{i C}}{\sum_{i \in \Omega_{W}} v_{i W}}=\left(\frac{\sum_{i \in \Omega_{C}} v_{i C}}{\sum_{i \in \Omega} v_{i C}} / \frac{\sum_{i \in \Omega_{W}} v_{i W}}{\sum_{i \in \Omega} v_{i W}}\right) \times \frac{\sum_{i \in \Omega} v_{i C}}{\sum_{i \in \Omega} v_{i W}}
$$


Similar to Feenstra (1994), Hummels and Klenow (2005), $\sum_{i \in \Omega} v_{i C} / \sum_{i \in \Omega} v_{i W}$ means extensive margin; if the kinds of product in China's export is more than the world's, than the extensive margin is bigger than 1, therefore, it expresses the meaning of product variety of China's export. $\sum_{i \in \Omega}^{\frac{\sum_{i \in \Omega} v_{i C}}{\sum_{i W}}}$ margin. $v$ stands for export value. It can be furthered decomposed into price and quantity, as equation (A2):

$$
\frac{\sum_{i \in \Omega} v_{i C}}{\sum_{i \in \Omega} v_{i W}}=\frac{\sum_{i \in \Omega} p_{i C} q_{i C}}{\sum_{i \in \Omega} p_{i W} q_{i W}}=\prod_{i}\left(\frac{p_{i C}}{p_{i W}}\right)^{w_{i}} \prod_{i}\left(\frac{q_{i C}}{q_{i W}}\right)^{w_{i}}
$$

$$
\text { The ratio } w_{i}=\frac{\frac{s_{i C}-s_{i W}}{\ln s_{i C}-\ln s_{i W}}}{\sum_{i}\left(\frac{s_{i C}-s_{i W}}{\ln s_{i C}-\ln s_{i W}}\right)}, s_{i} \text { stands for value share, } s_{i}=\frac{p_{i} q_{i}}{\sum_{i \in \Omega} p_{i} q_{i}}
$$

At last we can decompose the export ratio of China's ITC export into three margins, as equation (A3):

$$
R=\frac{\sum_{i \in \Omega c} v_{i c}}{\sum_{i \in \Omega_{W}} v_{i W}}=E X \times P \times Q=\left(\frac{\sum_{i \in \Omega c} v_{i c}}{\sum_{i \in \Omega} v_{i c}} / \frac{\sum_{i \in \Omega_{W}} v_{i W}}{\sum_{i \in \Omega} v_{i W}}\right) \times \prod_{i}\left(\frac{p_{i c}}{p_{i t}}\right)^{w_{i}} \times \prod_{i}\left(\frac{q_{i c}}{q_{i t}}\right)^{w_{i}}
$$

EX is extensive margin, which measures the variety of export. $\mathrm{P}$ is relative price of China's exports to the world average, which stands for the quality index. $\mathrm{Q}$ is the quantity ratio of China's exports to the whole world, which provides the relative quantity of China's ICT export. 